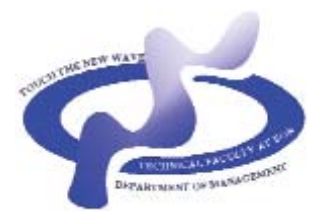

www.sjm06.com
Serbian

Journal

of

Management

\title{
OPTIMAL BUSINESS DECISION SYSTEM FOR MULTINATIONALS: A MULTIFACTOR ANALYSIS OF SELECTED MANUFACTURING FIRMS
}

\author{
Oforegbunam Thaddeus Ebiringa ${ }^{a *}$

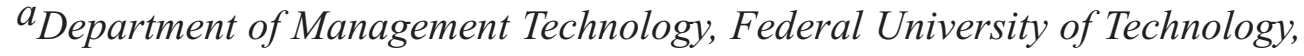 \\ Owerri, Nigeria
}

\begin{abstract}
Traditional MIS has been made more effective through the integration of organization, human and technology factors into a decision matrix. The study is motivated by the need to find an optimal mix of interactive factors that will optimize the result of decision to apply ICT to manufacturing processes. The study used Factor analysis model based on the sampled opinion of forty (40) operations/production managers and two thousand (2000) production line workers of three leading manufacturing firms: Uniliver Plc., PZ Plc, and Nigerian Breweries Plc operating in Aba Industrial Estate of Nigeria. The results shows that a progressive mixed factor loading matrix, based on the preferred ordered importance of resources factors in the formulation, implementation, monitoring, control and evaluation of ICT projects of the selected firms led to an average capability improvement of 0.764 in decision efficiency. This is considered strategic for achieving balanced corporate growth and development.
\end{abstract}

Keywords: integration, Efficiency, sustainability, strategy, eigenvalues, matrix

\section{INTRODUCTION}

Nowadays, business organizations are under intense competitive pressures due to the pervasive influence of globalization. Major changes are being experienced with respect to resources, markets, processes, and business strategies (Taşkın and Adalı; 2004; Nandan et al., 2010). This situation has led to a paradigm shift in business decision making. ICT (information communication technology) application has become strategic for supporting business decisions, especially for manufacturing enterprises (IMTR, 2000).

\footnotetext{
*Corresponding author: otebringa@yahoo.com
} 
Some models of business decision support systems have been developed. In this paper, we present a practical application of generic business decision support model codenamed Integrated Decision Support (IDS). The model consists of an overlapped integration of organization, human and technology variables over ICT infrastructure. However the IDS is modeled following the traditional methodology of automated information systems (AIS), which according to Ferguson et al (1991) and Irving (1997) is divided into four phased process of Planning, Feasibility study, Installation/Conversion from manual system and Operation/maintenance.

However, this approach has been criticized for failing to take into account the changing social and human resource dimensions of development. For this reason, efficiency of the compromised model advocated by IMTR (2000) is tested in this paper to address these concerns. The objective being to see the extent to which sustainability in decision making can be successively enhanced, through a progressive process of technology, organization and human factors introduction and loading.

The paper has been able to establish that the IDS model achieves a load matrix that mimics the conceptual four phases with better level of flexibility and stability than the disaggregated factor loads of the individual decision factors (technology, organization and human resources).

\subsection{Automated Information System (AIS) - The Key to Business Success}

AIS has become a vital part of business management. Today, high-speed networks efficiently link many parts of the business enterprise, enabling managers to efficiently generate and apply the vast amounts of information that are needed to support decisions in the areas of design, production, finance/accounting, marketing and general administration.

IT is a double-edged sword that provides success opportunities if well implemented and managed; as well as constitute threats if not well implemented and managed. The success side of IT application in business hinges on the fact that it provides means for business enterprises to enjoy the benefits of advanced tools and techniques of decision making, such as simulation, modeling, and robotics, which affords managers the latitude of dependable future predictions as well as sensitivity of possible changes in the decision factors and environments. All these help the manager to leverage the immediate action based on existence of a flexible, robust and result oriented database as well as lessons learnt.

On the other hand the threat side of IT application to business is occasioned by the fact that the IT supported decision system operates on the gabage-in-gabage-out (still depends on human input), implying that there still exist high possibility of suboptimal performance due to human error, which be innocent or intended to defraud the system . Other threats include environmental and technological risk such as (virus, internet fraud, systems' collapse etc. which may lead to stoppage of further operations of the business without prior warning). However, more importantly, IT is the changing agent that is driving modern business enterprises to respond more quickly to new threats and opportunities more than ever before. Manufacturing enterprises cannot afford to ignore AIS and the changes it brings (IMTR, 2000). However they must understand the 
modern enterprise as an integral business operation consisting of many activities, with strong interdependence between all functions, and is reflected by a great volume of information flow between them.

In former times, specific hardware and software systems are acquired for isolated individual operations, however, with the increasing pressure to reduce cost of operations, there is presently a strong need to integrate all isolated information systems of a manufacturing enterprise into a decision network in order to meet operational cost, schedule and quality requirements (Rehg and Kraeber, 2005).

\subsection{Optimal Decision Support System for Manufacturing Firms}

An information system model is a representation of concepts, relationships, constraints, rules, and operations to specify data semantics for a chosen domain of discourse, which in the case of manufacturing may include any of: product design, operations schedules, quality control, market information (demand and pricing) etc. The advantage of using an ICT model is that it provides a sharable, stable, and organized structure of information requirements for the domain context. An information system modeling language is a formal syntax that allows users to capture data semantics and constraints. In 1976, an Entity Relationship graphic notation was introduced to develop relational data models. Since then, languages for information system models have continued to evolve: the Integrated Computer Aided Manufacturing (ICAM), Definition Language 1 Extended (IDEF1X), the EXPRESS Language, and the Unified Modeling Language (UML) are some examples (Chen and Zhu, 2004;
Djordjevic et al., 2010).

Information system modeling is a technique for specifying the data requirements that are needed within the application domain. There are different practices in developing an information system model. The underlying methodologies for the recent modeling practices are based on three approaches:

- Entity-relationship (ER) approach,

- Functional modeling approach, and

- Object-oriented (O-O) approach.

The ER approach focuses on how the concepts of entities and relationships might be applied to describing information requirements. The emphasis of the functional modeling approach is placed on specifying and decomposing system functionality. The O-O approach focuses on identifying objects from the application domain first then operations and functions.

The model according to Chen and Zhu (2004) is complete, sharable, stable, extensible, well-structured, precise, and unambiguous. In general, the contents of an information model include a scope, information requirements, and a specification.

In implementing the information model itself, which is to be shared by different components of a business process or exchanged among systems, Zaina, et al (2005) posits it is necessary to determine if the data transfer is to be based on an inmemory storage structure, disk files, or a database management system. To streamline the information model design and implementation process, naming conventions and a glossary should be established. Different requirements of numerical precision and measurement units should be included in the model to maintain system flexibility. Industrial review will 
greatly enhance the system performance and user satisfaction.

The strategic IDS model assumes that the concept of management as obtains in business, revolves around how changing environmental factors (technology, organasation and human) can be integrated into the objective realization/decision making function as shown on Figure 1. The decision may be on what to produce, when to produce, how to produce, how to market, how to finance and revenues etc. However, profit maximization remains the central objective of all the above.

\subsection{Factor Analytic Model}

In this study, factor analytical techniques were adopted to assess the significance of the twelve factors affecting IT application

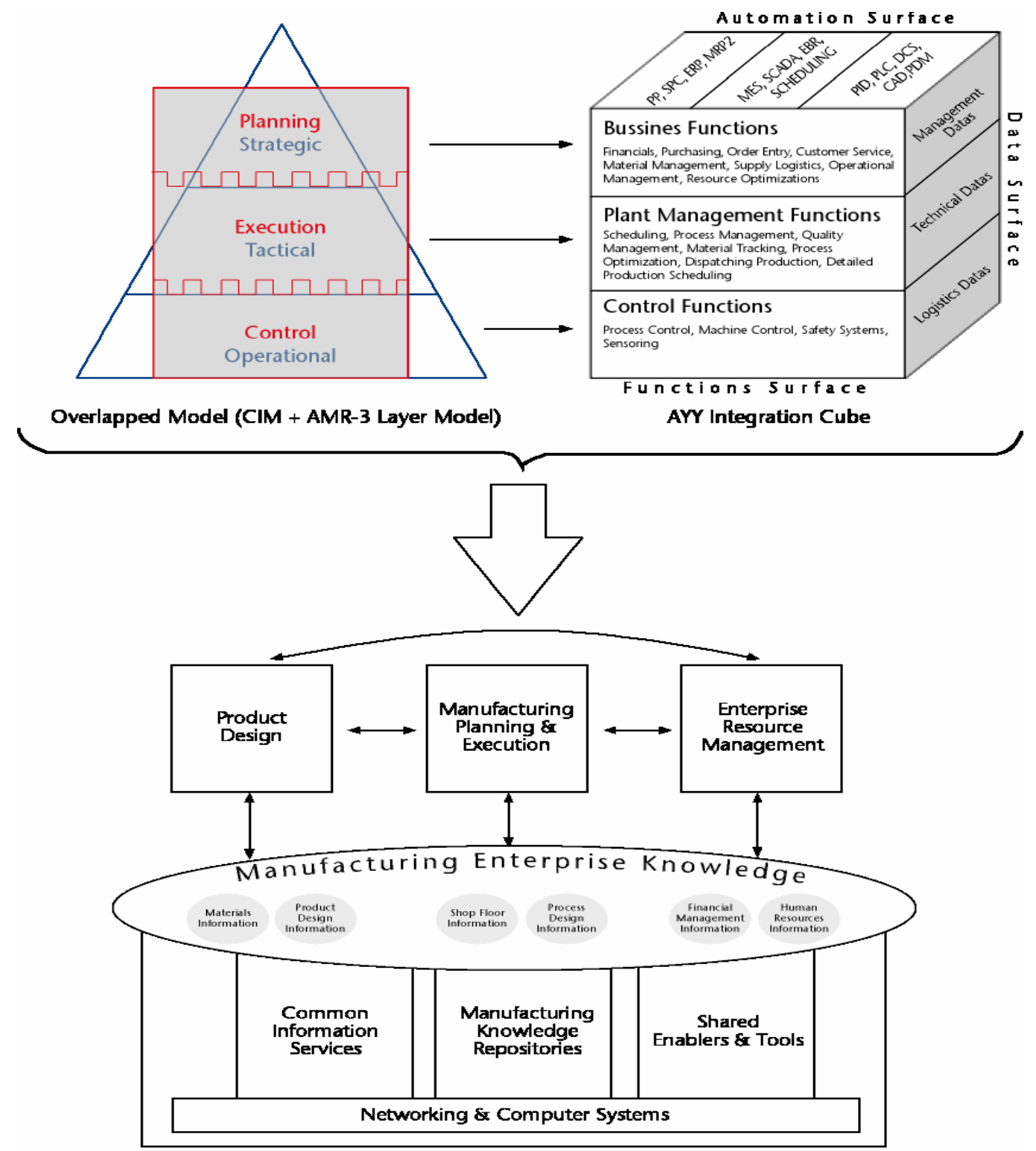

IT Infrastructure (IMTR Roadmap, 2000)

Figure 1. The strategic IDS model 
manufacturing process.

Furthermore, factor analysis is a method of quantitative multivariate analysis with the goal of representing the interrelationships among a set of continuously measured variables (usually represented by their interrelationships) by a number of underlying. Linearly independent reference variables called factors.

Factor analysis therefore seeks to collapse the numerous operating variables into fewer dimensions of interrelated attributes called principal components. The Eigenvalue would determine the principal components, which would be arthogonally varimax, rotated to obtain more evenly distributed variables among the components.

\section{THE EIGENVALUES}

The $\mathrm{n} \times \mathrm{n}$ matrix $\mathrm{A}$ has eigenvalues $\lambda$ if there exists a non-zero vector $\mathrm{x}$, called an eigenvector associated with $\lambda$, for which:

$$
\mathrm{Ax}=\lambda \mathrm{x}
$$

From the above model, it follows that the matrix $A-\lambda I$ is singular and therefore that $\operatorname{det}(\mathrm{A}-\lambda \mathrm{I})=0$. This is a polynomial equation in $\lambda$ of degree $n$ from which it follows that $\mathrm{A}$ as at most $\mathrm{n}$ eigenvalues. The polynomial $\operatorname{det}(\mathrm{A}-\lambda)$ is called the characteristic polynomial of A. Some roots of this characteristic equation may be repeated and we talk about the (algebraic) multiplicity of the eigenvalue in the same way as the multiplicity of roots of polynomials. In the event that the multiplicity of an eigenvalue is greater than the dimension of the vector space spanned by its associated eigenvalues, then the matrix is said to be defective.
Solving the eigenvalue problem, that is finding eigenvalues and associated eigenvectors, is, in general best achieved by methods other than solving the characteristic equation.

\section{INVERSE ITERATION}

Suppose that the smallest eigenvalue rather than the dominant one was required, the power method could be applied to the inverse matrix $\mathrm{A}^{-1}$ since the eigenvalyes of $A^{-1}$ are the reciprocals of those of A. But using the inverse matrix would be computationally expensive.

The inverse iteration algorithm for the smallest eigenvalue (using the Rayleigh quotient and normalizing son that $\|\mathrm{Xi}\|_{2}=1$ ) can therefore be summarized as follows:

Input: Matrix $\mathrm{A}$; required precision $\mathrm{E}$; initial vector $X_{1}$ and initial $\lambda_{1}$

Compute:

$$
\begin{aligned}
& \mathrm{X}_{0}=\mathrm{X}_{1} ; \lambda_{0}=\lambda_{1} \\
& \text { Compute }\left\|\mathrm{X}_{0}\right\|_{2} \\
& \mathrm{X}_{0}:=\mathrm{X}_{0}\left\|\mathrm{X}_{0}\right\|_{2} \\
& \text { Solve Ly }=\mathrm{X}_{0} \\
& \text { Solve UX } \mathrm{U}_{1}=\mathrm{y} \\
& \lambda_{1}:=\mathrm{X}_{\mathrm{i}}^{\mathrm{T}} \mathrm{X}_{0} \\
& \text { until }\left|\lambda_{1}-\lambda_{0}\right|<\in
\end{aligned}
$$

Output: Approximate eigenvalue 1/1 and eigenvector X1.

\section{ORIGIN SHIFTS}

The idea behind origin shifts is to use inverse iteration approach to find other eigen 
values. The eigen values of the matrix $A$ $\lambda_{0} \mid$ are precisely those of $A$ shifted by $\lambda_{0}$. That is $\lambda$ is an eigenvalue of $A$ if and only if $\lambda-\lambda_{0}$ is an eigen value of $A-\lambda_{0} \mid$. In particular the smallest eigen value of $A-\lambda_{0}$ l is the eigen value of $A$ close to $\lambda_{0}$ minus $\lambda_{0}$. Therefore to find the closest eigen value of $A$ to $\lambda_{0}$, we applied the inverse iteration algorithm to $\mathrm{A}-\lambda_{0} \mid$ and add $\lambda_{0}$ to the result. For this origin shift to be useful, we need reasonable approximations to the desired eigenvalues.

\section{RESULTS \& DISCUSSIONS}

The impact of the IDS model is analyzed using Factor analysis model based on the sampled opinion of forty (40) operations/production managers and two thousand (2000) production line workers of three manufacturing firms: Uniliver Plc., PZ Plc, and Nigerian Breweries Plc operating in Aba Industrial Estate of Nigeria to our survey questionnaire. The choice of the three firms is based on the fact that each of them has embarked on the programme of process automation as a strategic tool for improving the efficiency of managerial decisions since1998.

The results of the analysis as shown on Table 2, generated a progressively mixed factor loading matrix, based on the preferred ordered importance of technological, organizational and human resources factors in the formulation, implementation, monitoring, control and evaluation of the impact of the programme on the realization of the corporate objectives of each of the firms. The ordered preference of the factors were further classified into five decision clusters/components, which we consider as mimicking the phases in the automation programme of manufacturing firms.

Table 2. Normalized Integrated Factor Loading Matrix

\begin{tabular}{|l|l|l|l|l|l|}
\hline \multirow{2}{*}{ Decision factors } & \multicolumn{5}{|c|}{ Phases of Implementation/Decision Clusters } \\
\cline { 2 - 6 } & $\mathbf{1}$ & $\mathbf{2}$ & $\mathbf{3}$ & $\mathbf{4}$ & $\mathbf{5}$ \\
\hline $\mathrm{OF}_{1}$ & 0.873 & & & & \\
\hline $\mathrm{HF}_{1}$ & 0.845 & & & & \\
\hline $\mathrm{TF}_{1}$ & 0.738 & & & & \\
\hline $\mathrm{TF}_{2}$ & 0.730 & & & & \\
\hline $\mathrm{OF}_{2}$ & & 0.900 & & & \\
\hline $\mathrm{HF}_{2}$ & & 0.820 & & & \\
\hline $\mathrm{TF}_{3}$ & & 0.646 & & & \\
\hline $\mathrm{OF}_{3}$ & & & 0.923 & & \\
\hline $\mathrm{HF}_{3}$ & & & 0.716 & & \\
\hline $\mathrm{TF}_{4}$ & & & 0.536 & & \\
\hline $\mathrm{OF}_{4}$ & & & & 0.807 & \\
\hline $\mathrm{HF}_{4}$ & & & & 0.804 & \\
\hline $\mathrm{TF}_{5}$ & & & & 0.668 & \\
\hline $\mathrm{HF}_{5}$ & & & & & 0.760 \\
\hline $\mathrm{OF}_{5}$ & & & & & 0.758 \\
\hline $\mathrm{TF}_{6}$ & 3.186 & 2.366 & 2.175 & 2.279 & 2.211 \\
\hline Total Load score $_{\text {Variance Explained (\%) }} 31.435$ & 17.289 & 13.684 & 10.359 & 6.669 \\
\hline
\end{tabular}

Source: Result of Analysis with SPSS for Windows 
The result of the analysis shows that in the opinion of our respondents the automation programme of a manufacturing firm based on integration of technology, organization and human resources factors is principally phased into five as follows:

\section{Phase 1: Planning/Systems' Design}

The factor that initiates the automation programme is the management policy to embrace automation $\left(\mathrm{OF}_{1}\right)$, an organization factor. This is followed by the commissioning of design teams made up of experts $\left(\mathrm{HF}_{1}\right)$, (a human resource factor). The design teams generates designs made up of recommended hardware devices $\left(\mathrm{TF}_{1}\right)$, software devices $\left(\mathrm{TF}_{2}\right)$ as well as the associate cost budgets, time schedules and quality specifications (technology factors) and the human resource requirements and skill portfolio needed for successful implementation. This concludes the planning phase as the reports of all the above are submitted to top management for approval. This phase generates an average load score of 0.7965 , implying $79.65 \%$ level of success in IDS design.

\section{Phase 2: Unit level Implementation}

For the automation programme to move to this level top management must have to give its approval of the report to the design teams as well as release fund for successful implementation $\left(\mathrm{OF}_{2}\right)$, (an organization factor). This is followed by the commissioning of an implementation team made up of experts $\left(\mathrm{HF}_{2}\right)$ as well as training of existing staff and recruitment of new hands (a human resource factor). The implementation team shops the hardware and software devices $\left(\mathrm{TF}_{3}\right)$ for each of the units/departments (a technology factor). This phase generates an average load score of 0.7889 , implying $78.895 \%$ level of success in unit level implementation of IDS design.

Phase 3: Integration of Units into Local Area Network (LAN)

Having successfully automated individual units/departments of the manufacturing firm, the decision to move to next level -LAN is taken by the top management $\left(\mathrm{OF}_{3}\right)$ (an organization factor). This approval is granted by way of appointment of an implementation team to implement the already approved design as well as continuous training of operators $\left(\mathrm{HF}_{3}\right)$ (a human resource factor). The implementation team shops for hardware and software devices $\left(\mathrm{TF}_{4}\right)$ as per the approved design that ensures efficient data flow across units/departments. This phase generates an average load score of 0.7250 , implying $72.50 \%$ level of success in LAN implementation.

Phase 4: Integration of Factories into Wide Area Network (WAN)

If the phase 3 is evaluated and found successful, the automation programme moves to the next level "integration of all plants". The top management is equally required to grant approval and release the needed funds to implement the already approved design $\left(\mathrm{OF}_{4}\right)$ (an organization factor). However, technical teams are commissioned to implement this integration and further training implemented $\left(\mathrm{HF}_{4}\right)$, (a 
human resources factor). Hardware and software devices are introduced to facilitate the integration $\left(\mathrm{TF}_{5}\right)$, (a technology factor).

This phase generates an average load score of 0.7597 , implying $75.97 \%$ level of success in integration of factories into a WAN.

Phase 5: Functionality and Serviceability

The last but not the least in the automation phase is the functionality and serviceability of the installed systems. This is achieved through continuous capacity building of the operators $\left(\mathrm{TF}_{5}\right)$, as well as institution of a policy $\left(\mathrm{OF}_{5}\right)$, (an organization factor) that ensure continuous upgrade of the installed hardware, software and devices $\left(\mathrm{TF}_{6}\right)$ (a technology factor). This phase generates an average load score of 0.7370 , implying $73.70 \%$ level of success in maintenance and servicing of installed facilities to ensure functionality of the IDS.

\section{IDS Model and Phase transformation of Manufacturing Process}

Table 3 shows that in the opinion of our respondents the automation programme of a manufacturing firm based on integration of technology, organization and human resources factor can be progressively isolated into:

Series 1: only Technology factors

Series 1: Technology and Organisation factors

Series 3: Technology, Organisation and Human factors.

The effects of this progressive isolated integration on the advancement of the firm in the opinion of our respondents can be explained using Figure 2 statistics.

Figure 2 shows that progressive ordered integration of technology, organization and human resource factors as advocated for by IMTR (2000) leads to progressive transformation of manufacturing enterprises from lower levels of decision reliability to ones that are considered higher with more capability to improve reliability in decision making.

\section{CONCLUSION}

The application of the IDS model generated five successive interdependent phases for implementing automated decision support systems in the manufacturing industry. The systems design, unit level

Table 3. Load Matrix based on Progressive Integration of Decision Factors

\begin{tabular}{|l|c|c|c|c|c|c|}
\hline \multirow{2}{*}{ stages } & \multicolumn{6}{|c|}{ Series of Integration } \\
\cline { 2 - 7 } & $\begin{array}{c}\text { Series } \\
\mathbf{1}\end{array}$ & $\begin{array}{c}\text { Cumulative } \\
\text { Score }\end{array}$ & $\begin{array}{c}\text { Series } \\
\mathbf{2}\end{array}$ & $\begin{array}{c}\text { Cumulative } \\
\text { Score }\end{array}$ & $\begin{array}{c}\text { Series } \\
\mathbf{3}\end{array}$ & $\begin{array}{c}\text { Cumulative } \\
\text { Score }\end{array}$ \\
\hline Start & 0 & & 0 & & 0 & \\
\hline Phase 1 & 1.468 & 1.468 & 2.341 & 2.341 & 3.194 & 3.194 \\
\hline Phase 2 & 0.646 & 2.114 & 1.546 & 3.887 & 2.366 & 5.560 \\
\hline Phase 3 & 0.536 & 2.650 & 1.459 & 5.346 & 2.175 & 7.926 \\
\hline Phase 4 & 0.668 & 3.318 & 1.475 & 6.821 & 2.279 & 10.101 \\
\hline Phase 5 & 0.693 & 4.011 & 1.451 & 8.272 & 2.211 & 12.312 \\
\hline
\end{tabular}




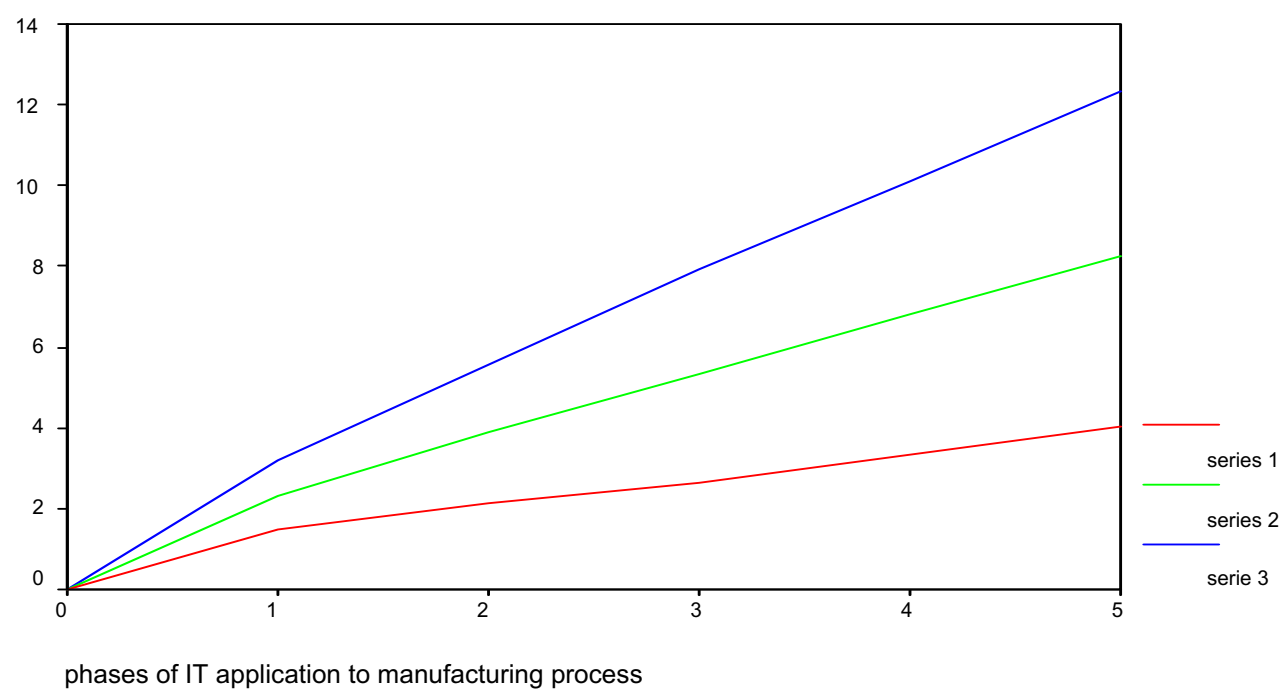

Figure 2: Manufacturing Process Cycle Factor Integration

implementation, integration of units within a factor into a LAN, integration of factories into a WAN and functionality and serviceability phases were identified as the critical phases as they generated integrated load scores of $0.80,0.79,0.73,0.76$ and 0.74 respectively were associated to each of them, implying $80 \%, 79 \%, 73 \%, 76 \%$ and $74 \%$ success in decision support to the manufacturing process.

Hence, the efficiency of traditional MIS development and implementation based on isolated technology, organization and human factor analysis has been made more effective through the integration of organization, human and technology variables over ICT platforms. The phases are successively interdependent and critically important for attainment of sustainability in management decision making, hence by considering the technical objectives of the MIS design in the context of organizational objectives and human resources needs, a fit is developed that balances the strategic business objectives of manufacturing firms with the changing economic, social, political and technology environments. This is what the IDS model has achieved.

\section{References}

Chen, Y., \& Zhu, J. (2004) Measuring Information Technology's Indirect Impact on Firm Performance, Information Technology and Management, 5: 9-22.

David, F. R. (1995). Concepts of Strategic Management, Englewood Cliffs, NJ: Prentice Hall, 117.

Djordjevic, P., Mihajlovic, I., Zivkovic, Z. (2010) Comparison of Linear and Nonlinear Statistics Methods Applied in Industrial Process Modeling Procedure, Serbian Journal of Management, 5(2): 189 - 198.

Ferguson, H. W. \& Gatewood, R. (1991) Strategic Planning for Office Automation, Information and Management, 21: 202-204.

Freund, Y. (1988) Critical Success Factors, Planning Review,16(4): 20.

IMTR Roadmap (2000). Integrated Manufacturing Technology Roadmapping Project, Information Systems Workshop 


\title{
ОПТИМАЛНИ СИСТЕМ ПОСЛОВНОГ ОДЛУЧИВАҢА ЗА МУЛТИНАЦИОНАЛНЕ КОМПАНИЈЕ: ВИШЕФАКТОРСКА АНАЛИЗА ОДАБРАНИХ ПРОИЗВОДНИХ КОМАПНИЈА
}

\author{
Oforegbunam Thaddeus Ebiringa ${ }^{a^{*}}$ \\ a Department of Management Technology, Federal University of Technology, \\ Owerri, Nigeria
}

\section{Извод}

Традиционални МИС се могу учинити још ефективнијим кроз интеграцију организације, људских и технолошких фактора у матрицу одлучивања. Ова студија је мотивисана потребом да се пронађе оптимални микс интерактивних фактора који ће оптимизирати резултат одлучивања у смислу примене ИЦТ у производном процесу. У студији је коришћен модел факторске анализе засновано на мишљењу узорка од 40 операционих/производних менаџера и 2000 радника са производне линије који раде у три водеће компаније Uniliver Plc., PZ Plc, и Nigerian Breweries Plc. Све компаније су део конзорцијума Aba Industrial Estate of Nigeria. Резултати показују да прогресивна мешана матрица факторских коефицијената, заснована на преференцама важности током формулације, имплементације, мониторинга, контроле и процене ИЦТ пројеката одабраних фирми, даје просечну могућност унапређења ефикасности одлучивања од 0.764. Ово се може сматрати стратешки важним за достизање равномерног корпоративног раста и развоја.

Кључне речи: интеграција, Ефикасност, одрживост, стратегија, матрица

Group and the IMTR Roadmapping Project Team.

Irving, R., \& Higgins, C. (1991). Office Information Systems, West Sussex, England: John Wiley \& Sons Ltd., 89.

Irving, R. (1997). Traditional and Emergent Planning Methods, Managing Transitions Management 6730, York University.

Nandan, S., Samaddar, S. G., \& Nandan, T. (2010) A Dynamic Model for Evaluation of Usefulness of Faculty Development Programmes in the Area of Business Management, Serbian Journal of Management, 5(2): 251-259.

Rehg, J. A., \& Kraeber, H. W. (2005). Computer Integrated Manufacturing, Third
Edition, Pearson Education, Inc.

Taşkın, H., \& Adalı, M. R. (2004) Technological Intelligence and Competitive Strategies: An Application Study with Fuzzy Logic, Journal of Intelligent Manufacturing, 15: 417-429.

Zaina, M. R., Roseb, C., Abdullahc, I., \& Masromd, M. (2005) The relationship between information technology acceptance and organizational agility in Malaysia, Information \& Management, 42 :829 839. 